\title{
Effects of heat treatments and edible shell coatings on egg quality after storage at room temperature
}

\author{
Cristina Henrique OLIVEIRA ${ }^{1 *}$ (1), Marcel Manente BOIAGO ${ }^{1}$, Andréia GUARAGNI²
}

\begin{abstract}
The objective of this study was to evaluate the effect of thermal treatments using different water temperatures and immersion times, as well as the application of eggshell coatings using edible materials on eggshell quality after storage for 4 weeks at room temperature $\left(22.8 \pm 4.4{ }^{\circ} \mathrm{C}\right)$. A total of 180 brown fresh eggs were distributed in a completely randomized design with six treatments and five replicates of six eggs each. The treatments consisted of a control group without any treatment (T1), three groups treated thermally: $56^{\circ} \mathrm{C} / 32$ minutes (T2); $56{ }^{\circ} \mathrm{C} / 20$ minutes (T3); $56{ }^{\circ} \mathrm{C} / 10$ minutes (T4); and two groups with gelatin $2 \%$ (T5) and $5 \% \mathrm{NaCl}$ solution (T6). After storage, it was found that the heat treatments at $56^{\circ} \mathrm{C}$ for 10,20 and 32 minutes provided maintenance of the albumen height, which reflected the values of the Haugh units but negatively influenced the albumen foam stability. The treatment with $5 \% \mathrm{NaCl}$ solution showed the lowest lipid oxidation rate and the best albumen foam stability. The proposed treatments (thermal or coatings), individually, caused significant improvements on some eggs quality markers evaluated after 30 days of storage.
\end{abstract}

Keywords: albumen; edible coating; haugh unit; heat treatment; lipid peroxidation.

Practical Application: Maintaining of the internal quality of the eggs using edible coatings and heat.

\section{Introduction}

Egg is a highly nutritious and complete food for human consumption. It contains essential amino acids of high biological value, very important in all phases of life (Ruxton et al., 2010; Wang et al., 2015). Due to their high perishability over the storage period, eggs undergo severe changes in their chemical and functional properties, which leads to significant economic losses to the egg industry (Perry et al., 2011; Yüceer et al., 2016).

The thermal treatment can delay the egg aging process, however most studies were focused on the microbiological quality and safety, offering to the market pasteurized eggs (Geveke et al., 2016). The pasteurization processes applied use mild temperatures for a long period, causing undesired changes such as partial denaturation of albumen proteins, and thus, rejection by the consumer (Kamotani et al., 2010; Lau et al., 2016).

An alternative to the thermal treatments are the edible coatings, which have the purpose of closing the pores of the egg shell, preventing the gas exchange with the external environment and maintaining the internal quality for a longer time during storage (Almeida et al., 2016). Several studies using different coatings have been published (Wardy et al., 2013; Yüceer \& Caner, 2014; Morsy et al., 2015), and positive and significant effects on egg quality parameters have been reported.

Gelatin is one of the proteins most studied as an edible coating because it has satisfactory functional properties in the formation of biofilms (Andrade et al., 2014). Salting whole eggs using high concentrations of sodium chloride is a common practice in Asia to preserve severe changes in the physical-chemical and structural properties, and not with the objective of maintaining freshness (Benjakul \& Kaewmanee, 2017).

In this context, there is a need to investigate the use of low cost and easy to obtain technologies with materials capable of promoting an improvement in egg conservation so that it reaches the consumers without significant quality losses. The objetive of the present study was to evaluate the effect of the thermal treatment using different water temperatures and immersion times, as well as the application of gelatin and saline solution on the internal quality of brown eggs after storage at room temperature.

\section{Materials and methods}

\subsection{Eggs}

A total of 180 unfertilized, whole brown fresh eggs were obtained from a commercial farm. The experiment was set up at the Laboratory of Technology of Products of Animal Origin of the Department of Animal Science of the State University of Santa Catarina, Chapecó city, Southern Brazil.

\subsection{Treatments}

Initially, a pilot test was performed to obtain the treatments and it was observed that temperatures above $60^{\circ} \mathrm{C}$ caused albumen desnaturation, even for short periods of time.

${ }^{1}$ Departamento de Zootecnia, Universidade do Estado de Santa Catarina - UDESC, Chapecó, SC, Brasil

${ }^{2}$ Departamento de Engenharia Química e de Alimentos, Universidade do Estado de Santa Catarina - UDESC, Pinhalzinho, SC, Brasil

*Corresponding author: cristina_hen@hotmail.com 
The treatments consisted of a control group without any treatment (T1) and three groups treated thermally: $56^{\circ} \mathrm{C} / 32$ minutes (T2); $56{ }^{\circ} \mathrm{C} / 20$ minutes (T3); $56{ }^{\circ} \mathrm{C} / 10$ minutes (T4); and two groups with gelatin $2 \%$ (T5) and $5 \%$ saline solution $(\mathrm{NaCl})(\mathrm{T} 6)$. Each heat treatment was applied individually according to the temperature and time established and previously described. The eggs were packed in stainless steel wire baskets and heat treated by immersion in water in a circulating water bath (Marconi - MA159) and temperature controller. When the water reached the programmed temperature, the eggs were immersed and the time counted in each treatment. After the thermoprocessing, the eggs were packed in cardboard trays with capacity for 30 units each (one per treatment) and stored.

The $2 \%$ gelatin coating was prepared by mixing $40 \mathrm{~g}$ of food grade unflavored gelatin of animal origin, preweighed on analytical balance, in 2 liters of distilled water for 5 minutes. After, the solution was heated to complete dissolution of the gelatin and cooled. The eggs were then dipped in this solution for 1 minute. The $5 \%$ sodium chloride $(\mathrm{NaCl})$ solution was prepared by solubilizing $100 \mathrm{~g}$ of food grade $\mathrm{NaCl}$ previously weighed on analytical balance in 2 liters of distilled water. The saline solution was heated to complete dissolution of the salt and used after cooling by dipping the eggs for 1 minute. After coating, the eggs were then dried and then packed in cardboard trays with a capacity of 30 units each (one per treatment) and stored.

The eggs were distributed in a completely randomized design (CRD) with thirty eggs per treatment, divided into five replicates of six eggs each. After the treatments, the eggs were packed in 30-unit capacity trays and stored at room temperature for 30 days (commercial shelf life). The temperature and humidity conditions of the environment were monitored daily during the storage period through the use of thermohygrometer (Incoterm $\mathrm{TH}$ 50). The maximum and minimum average temperature variation was $22.8^{\circ} \mathrm{C} \pm 2.9^{\circ} \mathrm{C}$ and $18.4^{\circ} \mathrm{C} \pm 3.1^{\circ} \mathrm{C}$, respectively. The variation of the maximum and minimum average moisture was $70.8 \% \pm 8.4 \%$ and $51.6 \% \pm 8.5 \%$, respectively.

\subsection{Egg quality assessment}

Egg quality after 30 days of storage at room temperature was evaluated by weight loss at storage (WLS \%), calculated as described by Yüceer et al. (2016). Specific gravity (SG) was determined according to Hempe et al. (1988), and the Haugh units $(\mathrm{HU})$ were calculated according to the equation decribed by Haugh (1937): HU = 100.log (Height + $7.57-1.7$. Weight $\left.{ }^{0.37}\right)$. The yolk index (YI) was calculated as the ratio of height $(\mathrm{mm})$ to yolk diameter $(\mathrm{mm})$.

The color of the yolk was determined by a colorimetric fan $\left(\mathrm{DSM}^{\circledR}\right)$ which has a range of values of colour intensity from 1 to 15 points. It were also determined the parameters luminosity $\left(\mathrm{L}^{\star}\right)$, red intensity $\left(\mathrm{a}^{\star}\right)$ and intensity of yellow $\left(\mathrm{b}^{\star}\right)$ using a colorimeter (Minolta CR-400). The yolks were manually separated from the albumen and egg shells were washed and dried at room temperature for 24 hours. Then, the yolks, shells and albumen were weighed to determine their percentage. The $\mathrm{pH}$ of the yolk and albumen were measured with a digital pH meter (Testo 205).
Lipid peroxidation was determined according to Giampietro et al. (2008) by measuring thiobarbituric acid reactive substances (TBARS), formed during the decomposition of lipid peroxides, using a spectrophotometer at $532 \mathrm{~nm}$. The compound 1,1,3,3-tetramethoxypropane (TMP) was used as a TBARS standard. The results were expressed as $\mathrm{mg} T \mathrm{TMP} / \mathrm{kg}$ of yolk.

Foam stability (FS) of the albumen was evaluated according to the methodology described by Phillips et al. (1987) with modifications. Briefly, 150g of albumen from each treatment was weighed and transferred to a conventional mixer (Black \& Decker - BAT300) where it was beaten until reaching a whipping consistency. Then, $26.00 \pm 0.21 \mathrm{~g}$ of the foam obtained was weighed into a glass funnel, and this was coupled in an Erlenmeyer flask to collect the drained liquid over 1 hour. The collected drained amount was weighed and the percentage of the drained amount was calculated using the following equation: $\% \mathrm{DR}=(\mathrm{Md}(\mathrm{t}) / \mathrm{Ms}){ }^{\star} 100$, where $\mathrm{Md}(\mathrm{t})$ is the mass in $\mathrm{g}$ of the drained amount, and Ms is the weight $(\mathrm{g})$ of the initial foam.

\subsection{Statistical analysis}

Data were submitted to the normality test followed by the analysis of variance. In cases of significant differences the means were submitted to the Tukey test at $5 \%$ of significance.

\section{Results}

There was a significant difference between the treatments for weight loss of eggs in storage (WL), specific gravity (SG), and percentages of yolk and shell (Table 1). The eggs that received $5 \%$ of salt (T6) showed the highest percentage of WLS and lower SG, being the only treatment to differ significantly from the control (T1) in these two parameters. Eggs for the control treatment showed a significantly lower percentage of yolk than those of treatment 2 (35.82\%).

Significant differences were observed for $\mathrm{HU}$, red and yellow intensity. Eggs that received heat treatment at $56^{\circ} \mathrm{C}$ for 32 and 20 minutes (T2 and T3, respectively) differed significantly from control eggs and coated eggs for the parameter HU.

The yellow coloration of the yolk is usually associated with good quality by consumers being this an important attribute. In this study, yolk color was evaluated through a DSM ${ }^{\circledR}$ colorimetric fan, and there was no significant difference between treatments. On the other hand the parameters $\mathrm{a}^{*}$ and $\mathrm{b}^{\star}$ showed statistical differences $(\mathrm{P}<0.05)$ between heat and coating treatments, however none of the treatments differed significantly from the control eggs.

The lipid peroxidation measured by the TBARS level showed a significant difference, where the T6 treatment had the lowest TBARS value (2.44 $\mathrm{mg} \mathrm{TMP} / \mathrm{kg}$ yolk), differing significantly from the control (T1) and the other treatments. The thermally treated eggs showed lower foam stability, differing significantly from the control group and those treated with coatings. The eggs covered with salt differed significantly from the control treatment showing a lower percentage of drainage. 
Table 1. Average values obtained for weight loss during storage (WL, \%), specific gravity (SG), percentage of yolk, albumen (Alb.) and shell, Haugh units ( $\mathrm{HU})$, yolk index (YI), luminosity $\left(\mathrm{L}^{\star}\right)$, red $\left(\mathrm{a}^{*}\right)$ and yellow intensity $\left(\mathrm{b}^{*}\right)$, yolk color fan (YCF), albumen $\mathrm{pH}(\mathrm{pH}$ A), yolk pH $(\mathrm{pH} \mathrm{Y})$, thiobarbituric acid reactive substances (TBARS, $\mathrm{mg}$ TMP/kg sample) and foam stability (FS, \%) of the eggs submitted to the different treatments and stored for 30 days at room temperature.

\begin{tabular}{|c|c|c|c|c|c|c|c|c|}
\hline Parameter & $\mathrm{T} 1$ & $\mathrm{~T} 2$ & T3 & $\mathrm{T} 4$ & T5 & T6 & $\mathrm{p}$-value & CV (\%) \\
\hline WL & $4.57^{\mathrm{BC}}$ & $5.15^{\mathrm{AB}}$ & $4.48^{\mathrm{BC}}$ & $4.07^{\mathrm{C}}$ & $4.78^{\mathrm{ABC}}$ & $5.62^{\mathrm{A}}$ & $<0.001$ & 8.91 \\
\hline SG & $1.033^{\mathrm{A}}$ & $1.029^{\mathrm{AB}}$ & $1.030^{\mathrm{AB}}$ & $1.034^{\mathrm{A}}$ & $1.029^{\mathrm{AB}}$ & $1.022^{\mathrm{B}}$ & 0.014 & 0.47 \\
\hline Yolk & $31.12^{\mathrm{B}}$ & $35.82^{\mathrm{A}}$ & $32.82^{\mathrm{AB}}$ & $31.80^{\mathrm{AB}}$ & $31.71^{\mathrm{AB}}$ & $32.84^{\mathrm{AB}}$ & 0.029 & 6.44 \\
\hline Alb. & 59.28 & 53.77 & 55.53 & 58.99 & 57.23 & 56.70 & 0.093 & 5.51 \\
\hline Shell & $9.60^{\mathrm{AB}}$ & $10.40^{\mathrm{A}}$ & $10.29^{\mathrm{A}}$ & $9.99^{\mathrm{AB}}$ & $8.41^{\mathrm{B}}$ & $10.45^{\mathrm{A}}$ & 0.025 & 9.54 \\
\hline $\mathrm{HU}$ & $50.26^{\mathrm{BC}}$ & $85.67^{\mathrm{A}}$ & $74.24^{\mathrm{A}}$ & $68.60^{\mathrm{AB}}$ & $49.38^{\mathrm{BC}}$ & $36.67^{\mathrm{C}}$ & $<0.001$ & 17.25 \\
\hline$a^{*}$ & $-3.39^{\mathrm{AB}}$ & $-2.31^{\mathrm{B}}$ & $-2.66^{\mathrm{B}}$ & $-3.72^{\mathrm{AB}}$ & $-4.79^{\mathrm{A}}$ & $-4.02^{\mathrm{AB}}$ & 0.011 & 29.28 \\
\hline$b^{*}$ & $59.00^{\mathrm{AB}}$ & $55.72^{\mathrm{AB}}$ & $51.02^{\mathrm{B}}$ & $58.54^{\mathrm{AB}}$ & $56.86^{\mathrm{AB}}$ & $61.22^{\mathrm{A}}$ & 0.050 & 8.35 \\
\hline YCF & 9.60 & 9.20 & 9.20 & 9.30 & 9.00 & 8.80 & 0.703 & 7.96 \\
\hline $\mathrm{pH} \mathrm{A}$ & 9.12 & 9.14 & 9.15 & 9.12 & 9.09 & 9.08 & 0.266 & 0.52 \\
\hline $\mathrm{pH} \mathrm{Y}$ & 7.16 & 7.24 & 6.43 & 6.71 & 6.44 & 6.31 & 0.120 & 9.36 \\
\hline
\end{tabular}

$\mathrm{A}, \mathrm{B}, \mathrm{C}-$ Mean values followed by different letters in the row indicate statistical difference by Tukey test $(\mathrm{P}<0.05) . \mathrm{CV}=$ coefficient of variation. $\mathrm{T} 1=\mathrm{control}$; $\mathrm{T} 2=56^{\circ} \mathrm{C} / 32$ minutes; $\mathrm{T} 3=56^{\circ} \mathrm{C} / 20$ minutes; $\mathrm{T} 4=56{ }^{\circ} \mathrm{C} / 10$ minutes; $\mathrm{T} 5=$ gelatin $2 \%$ and $\mathrm{T} 6=5 \%$ salt.

\section{Discussion}

Weight loss over storage is an expected process due to the movement of water and gases through the eggshell (Wardy et al., 2013). Salt shows high hygroscopicity, which caused the egg water to be attracted to the eggshell, which probably increased weight losses in eggs of T6 after storage. The eggshells coated with $2 \%$ of gelatin (T5) showed WL not different significantly to the heat treatments and the control group, which shows that the solution used (2\%) did not leave a suitable barrier able to prevent egg water losses to the external environment. Pissinati et al. (2014) observed improvements in weight maintenance when using $3 \%$ of gelatin.

Eggs that were immersed at $56{ }^{\circ} \mathrm{C}$ for 10 minutes (T4) showed lower weight loss and differed significantly from those of $\mathrm{T} 2$, but did not differ from the control eggs $(\mathrm{P}>0.05)$. These findings may be explained by the presence of a fine membrane called eggshell cuticule. The cuticle covers the entire surface of the shell protecting the opening of the pores, which hinders the escape of water and the penetration of bacteria through these pores (Muñoz et al., 2015). Washing the eggs can cause damage to the shell's cuticle and pore exposure, resulting in loss of moisture and deterioration of the internal quality (Gole et al., 2014). Such information may explain the differences found between treatments $\mathrm{T} 2$ and $\mathrm{T} 4$ for weight loss, since T4 eggs remained immersed in heated water for 10 minutes, while in T2 this exposure lasted 32 minutes, causing greater damage and removal of the shell cuticle.

The specific gravity (SG) of the T6 treatment eggs was significantly lower than that the eggs of T4 and control groups, and did not differ from the eggs of the other treatments. The difference found between is related to the egg chamber size. After storage, the egg ages and due to loss of $\mathrm{CO}_{2}$ and water to the external environment through the peel pores; the size of the air chamber increases, thus decreasing the density of the egg and directly reflecting the values of specific gravity. The increase in the size of the air chamber is related to the weight loss of the eggs. In this study, the T6 treatment presented the highest percentage of weight loss and the lowest value of SG, which explains this difference.

Eggs of the control treatment showed significantly lower percentages of yolk than those of the treatment 2 (35.82\%). This finding might be explained by the fact that the eggs of the T2 group were exposed for 32 minutes at $56^{\circ} \mathrm{C}$, which was the longest exposure time to heat. Such exposure for a prolonged period caused a greater loss of water from the albumen to the environment, thus, reducing the volume of albumen and, consequently, there was a higher percentage of yolk. According to Pissinati et al. (2014) there is a negative correlation between the percentage of albumin and yolk.

In Brazil, $\mathrm{HU}$ is not used as a parameter for egg classification; however in the USA this parameter is used and the eggs can be classified as AA quality, when $\mathrm{HU} \geq 72$; quality A, when $72>\mathrm{HU} \geq 60$; quality $\mathrm{B}$, when $60>\mathrm{HU} \geq 31$; and quality $\mathrm{C}$, when HU $<30$ (Caner \& Yüceer, 2015). In this study, the thermal treatments T2 and T3 maintained the values of $\mathrm{HU}$ higher than 72 even after 30 days of storage at room temperature, differing significantly from the control, which fit them into the AA quality standard according to the classification used in the USA. The heat treatment $\mathrm{T} 4$ maintained the average value of $\mathrm{HU}$ of the eggs between 72 and 60, classifying the eggs of this treatment as quality A, and the other treatments (T1, T5 and T6) showed quality $\mathrm{B}$, since $\mathrm{HU}$ values were lower than 60 . Higher values of $\mathrm{HU}$ for treatments 2 and 3 can be explained due to the partial denaturation of the albumen proteins caused by exposure to heat for a longer time $\left(56^{\circ} \mathrm{C}\right.$ for 32 and 20 minutes, respectively) when compared to $\mathrm{T} 4$, leading to condensation between these proteins which consequently maintains their height. 
Evaluating the coloration through a digital colorimeter it was found that eggs from the T5 treatment showed the lowest value for red intensity (-4.79), differing significantly from treatments T2 and T3 (-2.31 and -2.66, respectively), although the treatments did not differ significantly from the control group. Regarding the yellow intensity it can be observed that the eggs of treatment T3 $\left(b^{*}=51.02\right)$ differed significantly from T6 $\left(b^{*}=61.22\right)$, but there was no significant difference of the treatments with respect to the control. Higher $b^{\star}$ values indicate that the yolk is more yellow than blue $\left(+\mathrm{b}^{*}=\right.$ yellow; $-\mathrm{b}^{*}=$ blue $)$. It is known that carotenoids are compounds susceptible to oxidation, and a lower or higher oxidation rate of these compounds in T6 and T3, respectively, would be a possible explanation for the significant difference found between the $b^{*}$ values of these treatments.

$\mathrm{CO}_{2}$ has the ability to stabilize egg $\mathrm{pH}$. The increase in $\mathrm{pH}$ values is reported as evidence of $\mathrm{CO}_{2}$ loss to the external environment through the shell pores as the egg ages (Banerjee $\&$ Keener, 2012). No significant differences were observed in the results obtained in the $\mathrm{pH}$ analysis of albumin and yolk between treatments after 30 days of storage. However, in fresh eggs, the $\mathrm{pH}$ of the yolk was in the range of 6.08 to 7.00 and the $\mathrm{pH}$ of the albumen was close to 7.5 . This study confirmed that albumin $\mathrm{pH}$ increases after storage at room temperature, regardless of the type of treatment received (thermal or coatings).

Evaluating lipid peroxidation through TBARS levels, eggs coated with salt showed lowest values. This result is controversial since according to Mariutti \& Bragagnolo (2017), many studies point to salt as a pro-oxidant agent in meat products and suggest three mechanisms of salt action in lipid oxidation: release of iron ions from biomolecules, disruption of the cell membrane with exposure of lipid substrates to oxidizing agents, and ability to inhibit antioxidant enzymes. However, these mechanisms are not fully understood, and were evaluated in meats and their derivatives. There are also reports that salt has no effect under lipid oxidation (Mariutti \& Bragagnolo, 2017). Specifically in eggs, the ratio of salt to lipid oxidation and how it reflects in the malonaldehyde content (secondary product of lipid oxidation), is unknown and requires further investigation.

Thermally treated eggs showed lower foam stability, differing significantly from control and treatments with coatings. Exposure to heat by immersion in hot water bath in this study may have caused changes in the structure of the albumen proteins, which favors a higher drainage rate when compared to other non-thermal treatments. A study by Wang et al. (2015) demonstrated the occurrence of ovalbumin changes to S-ovalbumin (more heat-stable form) in eggs stored at higher temperatures. According to Yüceer \& Caner (2014), the transformation of ovalbumin to S-ovalbumin interferes with foam stability, and a positive correlation was found between S-ovalbumin content and drained volume.

Coating treatments showed a change in albumen structure, which was evident in the Haugh units analysis. Despite the loss in height, coated eggs showed the best results in the foam stability analysis, where the T6 treatment showed the lowest percentage of drainage among all treatments evaluated, differing significantly from the control. According to Xu et al. (2017), the addition of salt may enhance the interaction between the egg white proteins and the solvent, improving their viscosity, which could explain the increased egg white viscosity found in T6 treatment and thus, the lower value in drained amounts obtained when compared to the control (T1). The volume of liquid drained and the destabilization of the foam are also related to an increase in the albumen $\mathrm{pH}$, which interferes with its viscosity, resulting in the approximation between the bubbles of air present in the foam, leading to the rupture of these structures and adhesion between these bubbles (Alleoni \& Antunes, 2004). The stability of the egg foam is an indisputable parameter for egg quality and shell life of this product. Commercial use of egg white depends heavily on its foam stability in various applications in the food industry.

\section{Conclusion}

Temperatures above $60{ }^{\circ} \mathrm{C}$ are not feasible for the thermal treatment of whole eggs, even for short periods of time. Heat treatment at $56^{\circ} \mathrm{C}$ has beneficial effects on the internal quality, ensuring the maintenance of the Haugh unit. The use of $5 \%$ saline solution as a coating provided lower lipid oxidation rate (TBARS), and better foam stability to the eggs.

\section{References}

Alleoni, A. C. C., \& Antunes, A. J. (2004). Albumen foam stability and s-ovalbumin contents in eggs coated with whey protein concentrate. Revista Brasileira de Ciência Avícola, 6(2), 105-110. http://dx.doi. org/10.1590/S1516-635X2004000200006.

Almeida, D. S., Schneider, A. F., Yuri, F. M., Machado, B. D., \& Gewehr, C. E. (2016). Egg shell treatment methods effect on commercial eggs quality. Ciência Rural, 46(22), 336-341.

Andrade, R., Skurtys, O., Osorio, F., Zuluaga, R., Gañán, P., \& Castro, C. (2014). Wettability of gelatin coating formulations containing cellulose nanofibers on banana and eggplant epicarps. LebensmittelWissenschaft + Technologie, 58(1), 158-165. http://dx.doi.org/10.1016/j. lwt.2014.02.034.

Banerjee, P., \& Keener, K. M. (2012). Maximizing carbon dioxide content of shell eggs by rapid cooling treatment and its effect on shell egg quality. Poultry Science, 91(6), 1444-1453. http://dx.doi. org/10.3382/ps.2011-01504. PMid:22582306.

Benjakul, S., \& Kaewmanee, T. (2017). Sodium chloride preservation in duck eggs. In P. Hester (Ed.), Egg innovations and strategies for improvements (Chap. 39, pp. 415-426). Cambridge: Academic Press. http://dx.doi.org/10.1016/B978-0-12-800879-9.00039-1.

Caner, C., \& Yüceer, M. (2015). Maintaining functional properties of shell eggs by ultrasound treatment. Journal of the Science of Food and Agriculture, 95(14), 2880-2891. http://dx.doi.org/10.1002/ jsfa.7029. PMid:25427526.

Geveke, D. J., Gurtler, J. B., Jones, D. R., \& Bigley, A. B. W. (2016). Inactivation of Salmonella in shell eggs by hot water immersion and its effect on quality. Journal of Food Science, 81(3), M709-M714. http://dx.doi.org/10.1111/1750-3841.13233. PMid:26878421.

Giampietro, A., Scatolini, A. M., Boiago, M. M., Coró, D. M. O., Souza, H. B. A., Souza, P. A., \& Pizzolante, C. C. (2008). Estudo da metodologia de TBARS em ovos. Revista do Avisite, 13, 18-18.

Gole, V. C., Chousalkar, K. K., Roberts, J. R., Sexton, M., May, D., Tan, J., \& Kiermeier, A. (2014). Effect of egg washing and correlation between eggshell characteristics and egg penetration by various Salmonella typhimurium strains. PLoS One, 9(3), 1-12. http://dx.doi. org/10.1371/journal.pone.0090987. PMid:24621821. 
Haugh, R. R. (1937). A new method for determining the quality of an egg. US Egg Poultry, 39, 27-49.

Hempe, J. M., Lauxen, R. C., \& Savage, J. E. (1988). Rapid determination of egg weight and specific gravity using a computerized data collection system. Poultry Science, 67(6), 902-907. http://dx.doi.org/10.3382/ ps.0670902. PMid:3413014.

Kamotani, S., Hooker, N., Smith, S., \& Lee, K. (2010). Consumer acceptance of ozone-treated whole shell eggs. Journal of Food Science, 75(2), S103-S107. http://dx.doi.org/10.1111/j.1750-3841.2009.01468.x. PMid:20492254.

Lau, S. K., Thippareddi, H., Jones, D., Negahban, M., \& Subbiah, J. (2016). Challenges in radiofrequency pasteurization of shell eggs: coagulation rings. Journal of Food Science, 81(10), E2492-E2502. http://dx.doi.org/10.1111/1750-3841.13440. PMid:27650700.

Mariutti, L. R. B., \& Bragagnolo, N. (2017). Influence of salt on lipid oxidation in meat and seafood products: A review. Food Research International, 94, 90-100. http://dx.doi.org/10.1016/j. foodres.2017.02.003. PMid:28290372.

Morsy, M. K., Sharoba, A. M., Khalaf, H. H., El-Tanahy, H. H., \& Cutter, C. N. (2015). Efficacy of antimicrobial pullulan-based coating to improve internal quality and shelf-life of chicken eggs during storage. Journal of Food Science, 80(5), M1066-M1074. http://dx.doi. org/10.1111/1750-3841.12855. PMid:25847630.

Muñoz, A., Dominguez-Gasca, N., Jimenez-Lopez, C., \& RodriguezNavarro, A. (2015). Importance of eggshell cuticle composition and maturity for avoiding trans-shell Salmonella contamination in chicken eggs. Food Control, 55, 31-38. http://dx.doi.org/10.1016/j. foodcont.2015.02.028.

Perry, J. J., Rodriguez-Saona, L. E., \& Yousef, A. E. (2011). Quality of shell eggs pasteurized with heat or heat-ozone combination during extended storage. Journal of Food Science, 76(7), S437-S444. http:// dx.doi.org/10.1111/j.1750-3841.2011.02294.x. PMid:21819400.
Phillips, L. G., Haque, Z., \& Kinsella, J. E. (1987). A method of the measurement of foam formation and stability. Journal of Food Science, 53(4), 1074-1077. http://dx.doi.org/10.1111/j.1365-2621.1987. tb14279.x.

Pissinati, A., Oba, A., Yamashita, F., Silva, C. A., Pinheiro, J. W., \& Roman, J. M. M. (2014). Internal quality of eggs subjected to different types of coating and stored for 35 days at $25^{\circ} \mathrm{C}$. Semina: Ciências Agrárias, 35(1), 531-540. http://dx.doi.org/10.5433/1679-0359.2014v35n1p531.

Ruxton, C. H. S., Derbyshire, E., \& Gibson, S. (2010). The nutritional properties and health benefits of eggs. Nutrition \& Food Science, 40(3), 263-279. http://dx.doi.org/10.1108/00346651011043961.

Wang, X., Wu, S., Zhang, H., Yue, H., Qi, G., \& Li, J. (2015). Effect of dietary protein sources and storage temperatures on egg internal quality of stored shell eggs. Animal Nutrition, 1(4), 299-304. http:// dx.doi.org/10.1016/j.aninu.2015.12.003. PMid:29767081.

Wardy, W., Torrico, D. D., Herrera Corredor, J. A., No, H. K., Zhang, X., Xu, Z., \& Prinyawiwatkul, W. (2013). Soybean oil-chitosan emulsion affects internal quality and shelf-life of eggs stored at 25 and $4^{\circ} \mathrm{C}$. International Journal of Food Science \& Technology, 48(6), 1148-1156. http://dx.doi.org/10.1111/ijfs.12068.

Xu, L., Zhao, Y., Xu, M., Yao, Y., Nie, X., Du, H., \& Tu, Y. (2017). Effects of salting treatment on the physicochemical properties, textural properties, and microstructures of duck eggs. PLoS One, 12(8), 1-17. http://dx.doi.org/10.1371/journal.pone.0182912. PMid:28797071.

Yüceer, M., \& Caner, C. (2014). Antimicrobial lysozyme-chitosan coatings affect functional properties and shelf life of chicken eggs during storage. Journal of the Science of Food and Agriculture, 94(1), 153-162. http://dx.doi.org/10.1002/jsfa.6322. PMid:23893388.

Yüceer, M., Aday, M. S., \& Caner, C. (2016). Ozone treatment of shell eggs to preserve functional quality and enhance shelf life during storage. Journal of the Science of Food and Agriculture, 96(8), 27552763. http://dx.doi.org/10.1002/jsfa.7440. PMid:26329299. 